\title{
INNOVATION CONSIDERATIONS IN MERGER CONTROL AND UNILATERAL CONDUCT ENFORCEMENT
}

\section{Professor Ioannis Kokkoris*}

\begin{abstract}
Non price considerations in merger control and unilateral conduct enforcement have been elements of the competition authorities' assessment in the last few decades. Recently a revamped emphasis on such factors and in particular on the importance of innovation has characterised the European Commission's enforcement practice. The paper looks into merger control cases as well as two unilateral conduct cases (Microsoft and Google Shopping) and discusses the approach the European Commission has taken on the impact of concentrations as well as of abusive conducts on innovation. The paper argues that the approach the European Commission takes in assessing innovation in merger control is pragmatic and appropriate for dynamic competition that characterises innovative markets. In relation to the assessment of the harm on innovation in unilateral conduct cases, the paper emphasizes the need for a balanced approach that prevents an adverse impact on innovation incentives of the dominant company while at the same time maintains a robust approach to competition harm induced by abusive conducts.
\end{abstract}

Keywords: innovation, merger control, unilateral conduct, remedies, fines JEL codes: $K 21, L 41$

\footnotetext{
* Professor Ioannis Kokkoris, Chair in Law and Economics, Centre for Commercial Law Studies, Queen Mary University London. I am very grateful to Nandini Pahari for excellent research assistance. All errors and omissions belong to the author.
} 


\section{Introduction}

Recent trends in the European Commission's ('Commission') approach to merger control and unilateral conduct enforcement relates to concerns about non-price competition factors such as quality and innovation. Innovation has always been considered as one of the main parameters of competition, along-side price, quantity, quality and choice, but has recently attracted a lot of attention by enforcers and academics as a result of some recent decisions. ${ }^{1}$

An interesting observation of markets driven by innovation is that neither price nor quantity plays any decisive role since the services may not be monetized on the consumer side (there is no price expressed in terms of monetary terms) and the marginal costs can be negligible. The only parameters that can be used as yardsticks to determine the effects on fair competition in such markets are quality, innovation and choice. The Commission's stance in the Google case $e^{2}$ is one of the best examples that focuses precisely on these non-price parameters where the Commission observed that Google shopping results denied European consumers a genuine choice of service and the full benefits of innovation. ${ }^{3}$

\footnotetext{
${ }^{1}$ See judgements C-413/06 P Bertelsmann; T-168/01 Glaxo; and C-413/14 Intel.

${ }^{2}$ See Case AT.39740 Google Search (Shopping).

${ }^{3}$ Commission Vestager in Case AT.39740 Google Search (Shopping).
} 
New technologies that displace existing markets are commonly referred to as 'dynamic competition' and are contrasted with 'competition in the market' or 'static competition' where competition takes place on the basis of price and output. ${ }^{4}$ Firms must sustain and enhance their innovation potential as a means of achieving dominance or to fend off challengers. As Gifford and Kurdle note, new challengers to existing technologies frequently enter the market, and unsuccessful challengers exit. ${ }^{5}$ Katz and Shapiro ${ }^{6}$ argue that in markets where innovation plays a role, the tendency for the market to exhibit rapid innovation means that new products will emerge which can and do upset and even replace the status quo. This tendency is the oil to the fire of innovation that drives such markets.

Arguments have been raised that the positive correlation between innovation and technological markets, such as the online search market, would warrant exceptions in terms of competition law, as the market naturally tends through innovation to market power and competition works on the basis of competition for the market. ${ }^{7}$ Larouche argues that competition for the market which usually goes in tandem with a dominant position,

\footnotetext{
${ }^{4}$ Graef, I., Wahyuningtyas, S. Y., Valcke, (2014), How Google and others upset competition analysis disruptive innovation and European competition law, 25th European Regional Conference of the International Telecommunications Society (ITS), Brussels, Belgium, 22-25 June 2014, http//hdl.handle.net/10419/101378. ${ }^{5}$ Gifford D, Kurdle R., Antitrust approaches to dynamically competitive industries in the united states and the European Union, Journal of Competition Law \& Economics, 7(3), 695-731.

${ }^{6}$ Katz M., and Shapiro C., Systems Competition and Network Effects (1994) 8(2) Journal of Economic Perspectives, 93.

${ }^{7}$ Indicatively Diez F., Google, in the Aftermath of Microsoft and Intel The Right Approach to Antitrust Enforcement in Innovative High Tech Platform Markets? (June 12, 2012 Centro Universitario Villanueva), Geiger A., Thou shalt not dominate, Manne G., and Wright J., Innovation and the limits of Antitrust (2010) 6 Journal of Competition Law and Economics 171.
} 
provides stronger incentives for breakthrough innovation, since the whole market is the prize of the innovation efforts. ${ }^{8}$

Economists around the world have tried to analyze the correlation between innovation and competition very extensively throughout the years. Schumpeter ${ }^{9}$ claimed that innovation increases when the market is less competitive. He argues that decreased competition in a market leads to more innovation. ${ }^{10}$ As a consequence of low competition, companies could focus more on post-innovation and $R \& D$ processes rather than price and output competition in the market. In addition, if price competition arose in the market, the market leader would probably be forced to invest in innovation in order to secure its place instead of encouraging companies to take the role of the leading rivals in the market. By contrast, Arrow ${ }^{11}$ believed that in fact this pressure in the market leads to innovation growth since companies in the competitive market would intend to generate better or more cost-efficient products in order to draw away potential challengers. Thus, an innovating company would be able to attract

\footnotetext{
${ }^{8}$ Larouche P., The European Microsoft Case at the Crossroads of Competition Policy And Innovation, TILEC Discussion Paper No 2008-021

9 Joseph Schumpeter, Socialism, capitalism and democracy, Harper and Brothers $\left(5^{\text {th }}\right.$ edn, George Allen \& Unwin Ltd, 1976)

10 Joseph A. Schumpeter, Capitalism, Socialism And Democracy (1st edn, 1942) http://cnqzu.com/library/Economics/marxian\%20economics/Schumpeter,\%20Joeseph-

Capitalism,\%20Socialism\%20and\%20Democracy.pdf

${ }^{11}$ Kenneth Arrow, 'Economic Welfare and the Allocation of Resources for Invention' in The Rate and Direction of Inventine Activity in Nelson ed.,Princeton University Press, 1962.
} 
sales from its rivals. Arrow argues that an increase in competition in the market leads to more innovation. ${ }^{12}$

The issue however is not with respect to the debate whether innovation is directly or inversely proportional to competition in the market. The real challenge, while analyzing the nexus between innovation and competition, is to find a reasonable answer to the question whether the existing competition law frameworks and regulators around the world have sufficient means and tools to determine the effects of competition on innovation and vice-versa. The ever-changing technologies and digitalization of markets may have induced progress and advancement at various levels of the economy. But at the same time, their overreaching impact on the economy and on consumer welfare in the long run is yet ambiguous. In such dynamic times, it is very important for us to determine whether sophisticated regulators like the Commission is well-equipped to deal with the complicated non-price issues like innovation in competition enforcement.

The aim of this paper is to discuss how the Commission has approached the issues related to innovation in merger control and unilateral conduct cases and what challenges it faced while determining the applicability of competition law to markets characterized by innovation. The paper is going to discuss the two seminal unilateral conduct cases, Microsoft and Google, along-with various merger control decisions to analyze the Commission's approach in handling the complexities related to the assessment of competition in innovation driven markets.

\footnotetext{
${ }^{12}$ Competition Policy Brief EU Merger Control And Innovation (1st edn, European Commission 2016) $<$ http://ec.europa.eu/competition/publications/cpb/2016/2016_001_en.pdf>
} 
The Commission's approach to innovation in unilateral conduct cases seems to be less developed due to the fewer number of cases compared to merger control. Two unilateral conduct cases where the potential harm on innovation played a role and this paper will discuss and contrast is Microsoft ${ }^{13}$ and Google Shopping ${ }^{14}$ (hereinafter "Google"). We will focus only on these two cases as Microsoft is the first case in the high-tech software sector where the Commissions refers to innovation as part of its unilateral conduct assessment, and Google is the most recent example with Google Android ${ }^{15}$ for which though there is still no published decision. ${ }^{16}$ Thus, we will how the approach to the assessment of innovation has evolved. Other unilateral conduct cases where the impact of the conduct on innovation was relevant albeit to a varying degree include Intel, ${ }^{17}$ Tomra $^{18}$ and Qualcomm. ${ }^{19}$

\footnotetext{
1337792 MICROSOFT

1439740 Google Search (Shopping)

1540099 Google Android

${ }^{16}$ At the time of writing.
}

${ }^{17}$ See section V.5 of the decision. Indicatively, (139) Innovation is, together with price, one of the main factors that triggers demand in the $x 86$ industry. The very high research and development (R\&D) and production costs can usually only be recovered if new inventions can be sold before the competitor responds with a more innovative product. (140) The pace of innovation is rapid. Rapid innovation means quick increases in CPU transistor density and quick improvements in the CPU architecture.

${ }^{18}$ Innovation is only mentioned in paragraph 100 of the Commission's decision. Although Tomra's internal documents also mention normal means of competition, such as product innovation, an expansion of its product portfolio and customer satisfaction as barriers for competitors ${ }^{192}$, long-term preferred supplier contracts or high volume block orders with all major customers are often referred to as key elements in Tomra's policy of preventing market entries or denying market access to competitors. [confidential]

${ }^{19}$ In Qualcomm (Qualcomm/Icera, predation, Case 39711) the Commission does not refer to the impact on innovation. In the press release announcing the statement of objections for predation and exclusivity 
While, the remedies in the merger decisions we will analyse, have sought to ensure that innovation is not harmed as a result of the merger, the size of the fines in the unilateral conduct cases as compared to the dominant undertakings' budget devoted to R\&D has the potential to mitigate the innovation drive of these undertakings. Merger control is based on an ex ante assessment of potential harm arising from a concentration, thus any imposed remedies aim at preventing this harm from arising. Unilateral conduct enforcement is an ex post assessment of harm induced by the intentional abuse by a dominant company of its market power, thus fines in such cases have a deterrence as well as punitive element.

Section I will discuss how innovation became a very important non-price factor in competition assessment. Section II will then discuss briefly the main economic theories behind the relevance of innovation for competition enforcement and will analyse the role of innovation in merger control and unilateral conduct cases. Section III will assess the potential impact of fines on the innovation drive of dominant undertakings.

payments, the Commission mentions the relevance of innovation in relation to the exclusivity payments case (Case 40220). 


\section{Innovation as a non-price competition factor}

The most usual form of consumer harm arising in competition enforcement relates to an increase in the price of the relevant products/services. In addition to price, competition harm as a result of a merger can arise in relation to non-price parameters such as the quantity sold, service quality, product range ${ }^{20}$ product quality, ${ }^{21}$ geographical location, productive capacity and innovation. ${ }^{22}$ The ability of firms to adjust these elements, and also the time within which they can do so, will depend upon the market concerned. ${ }^{23}$

The technological evolution and revolution ${ }^{24}$ over the last few decades have demanded a revised approach in regulating competition in such markets whereby intervention by competition regulators would no longer revolve primarily around the creation or the strengthening of market power, but around the likely effects of a conduct or transaction on innovation. $^{25}$ This would require alteration in the yardsticks and factors that the Commission has conventionally adapted for competition law analysis. It needs to be

20 See, for example, Proposed acquisition of Ottakar's plc by HMV Group plc through Waterstone's Booksellers Ltd, CC, May 2006, and Anticipated acquisition by Boots Group plc of Alliance UniChem plc, OFT decision ME/2134/05, May 2006.

${ }^{21}$ Proposed acquisition of Ottakar's plc by HMV Group plc through Waterstone's Booksellers Ltd, May 2006.

${ }^{22}$ Carl Zeiss Jena GmbH and Bio-Rad Laboratories Inc: a report on the proposed acquisition of the microscope business of Bio-Rad Laboratories Inc, CC, May 2004.

${ }^{23}$ UK Merger Assessment Guidelines, CC2 (Revised) / OFT1254

${ }^{24}$ Klaus Schwab, The Fourth Industrial Revolution (WEF 2016).

25 Pablo Ibáñez Colomo Restrictions on Innovation in EU Competition Law http://eprints.lse.ac.uk/64888/1/Ibanzez\%20Colomo_Restrictions\%20on\%20innovation_2016.pdf. 
ascertained that while price is certainly an important factor for many consumers, a simple focus on price from the perspective of a competition regulator, poses a number of problems. Consumers may face a non-price-related detriment such as access, poor quality, lack of information, reduced choice, or less innovation. Price may not be the primary factor in determining demand side decisions in all types of markets and price may not be the main means of competition between the incumbents in a market. Thus, alternative means of competition can range from entirely non-economic ones to those that retain focus on economic objectives without however focusing exclusively on the price criterion.

Thus, even though price has traditionally been the main parameter for competition, in the light of the ever-changing economies and fast-growing dynamic sectors, this trend has been diluted. The evolution of digitalization and online business environment has imposed challenges to competition regulators around the world as they find it difficult to cultivate apt tools for assessment in markets where competition is taking place on the basis of the level and type of innovation. ${ }^{26}$

Competition regulators around the world agree that economics of dynamic markets work very differently in comparison to static markets. In a static competition setting, firms are under pressure to operate at lowest cost (productive efficiency) and to best utilize the limited resources (allocative efficiency), with the most efficient products being reflected in the lowest price (static efficiency). Dynamic competition on the other hand, starts from a different assumption. Here, firms compete to create products with the highest quality,

\footnotetext{
${ }^{26}$ Graef, Inge; Wahyuningtyas, Sih Yuliana; Valcke, Peggy: Conference Paper How Google and others upset competition analysis: disruptive innovation and European competition law 25th European Regional Conference of the International Telecommunications Society (ITS), Brussels, Belgium, 22-25 June 2014.
} 
which tends to result in the introduction of new products leading to dynamic efficiency. Whilst price is the distinctive indicator in static efficiency, dynamic efficiency can be indicated by different proxies in which innovation plays a prominent role, such as product innovation reflected in the introduction of new products and services; process innovation indicated by improvement of production technologies; an increase in choices for consumers, and an increase in the quality of products. ${ }^{27}$ Therefore, assessing antitrust issues in such markets may become complicated and requires more sophisticated frameworks to rectify competition law concerns.

Several legislative provisions around the world address innovation and other non-price parameters in assessing antitrust issues. ${ }^{28}$ The Commission acknowledges in its guidelines on the assessment of horizontal and non-horizontal mergers ('EU Guidelines'), ${ }^{29}$ the nonprice dimensions of effective competition such as high quality, a wide choice of goods and services, and innovation, and takes the stance that its mission is to prevent mergers that
${ }^{27}$ Ibid.
28
The
UK
merger
guidelines

(https://assets.publishing.service.gov.uk/government/uploads/system/uploads/attachment_data/file/284449/ OFT1254.pdf) have incorporated price and non-price parameters of a firm's competitive offer to its customers, that can be worsened as a result of an anticompetitive merger. In 2010 the US FTC and US DOJ issued their revised Horizontal Merger Guidelines ('US Guidelines'). These updated US Guidelines incorporate non-price considerations merger in analysis. https://www.ftc.gov/sites/default/files/attachments/merger-review/100819hmg.pdf

${ }^{29}$ Commission (EU) Guidelines on the assessment of horizontal mergers under the Council Regulation on the control of concentrations between undertakings [2004] OJ C 31/3, para. 8 and Commission (EU) Guidelines on the assessment of non-horizontal mergers under the Council Regulation on the control of concentrations between undertakings [2008] OJ C 265/7, para. 10 
would deprive customers of these benefits by significantly increasing the market power of firms. An increase in market power in that regard refers to 'the ability of one or more undertakings to profitably increase prices, reduce output, choice or quality of goods and services or diminish innovation' [emphasis added].${ }^{30}$ It has convincingly been argued that these dimensions of competition are 'of particular importance in the Internet, broadcast television, and radio industries, where the competition extends beyond advertising prices'. ${ }^{31}$ In that respect, considering the inclusion in a merger analysis of markets in which the quality rather than the price of the products offered is relevant and examining the impact of a concentration on non-price competition are legitimate issues of consideration in merger control enforcement.

Averitt and Lande ${ }^{32}$ illustrate the importance of non-price factors in competition assessment by giving the example of a merger in the book publishing sector. They note that, while such a concentration may not necessarily result in higher prices, it is likely to lead to a decrease in editorial diversity and 'thus, to a narrowing of the competing marketplace options expressed in terms of the types of titles offered' which can be challenged under the 'ordinary, universal standards of Section $7,{ }^{33}$ once that Section has been properly construed

\footnotetext{
${ }^{30}$ Commission (EU) Guidelines on the assessment of horizontal mergers under the Council Regulation on the control of concentrations between undertakings [2004] OJ C 31/3, para. 8 and Commission (EU) Guidelines on the assessment of non-horizontal mergers under the Council Regulation on the control of concentrations between undertakings [2008] OJ C 265/7, para. 10

${ }^{31}$ Stucke M., Grunes A., Big Data and Competition Policy, OUP, 279

${ }^{32}$ Averitt, N./Lande, R., "Using the 'Consumer Choice' Approach to Antitrust Law, 74 Antitrust L.J. (2007), pp. $175-264$

${ }^{33}$ Section 7 of the Clayton Act.
} 
to recognize the role of options and of non-price competition.' ${ }^{34}$ Stucke and Grunes take the same position in discussing how US antitrust law can be modified so that it can include in the relevant analyses the marketplace of ideas. ${ }^{35}$ These arguments, which suggest a change in approach and thus a different interpretation of the relevant legislative instruments in order to assess the impact of a concentration on editorial competition, are equally valid for the Commission's relevant decision-making. In HMV/Ottakar's ${ }^{36}$ the UK Competition Commission argued that competition in book retailing at the local level between existing stores is concentrated on two non-price factors, range of titles in stock and quality of instore service. It added that non-price competition encompasses principally competition on range and service.

The adoption of non-price factors of competition as an essential factor in assessing consumer harm has also been incorporated in the debate regarding the aims of competition law. To refer to such an example proponents of a 'consumer choice' standard ${ }^{37}$ argue that it would better accommodate aspects such as short-term variety, non-price competition and long-term innovation that seem to pose difficulties when assessed by means of the consumer welfare standard. Proponents have referred to particular cases in which the 'consumer choice' criterion would seem to be crucial, such as Microsoft, ${ }^{38}$ where in its

\footnotetext{
${ }^{34}$ Ibid.

${ }^{35}$ Stucke M., Grunes A., Big Data and Competition Policy, OUP, 298

${ }^{36}$ https://www.gov.uk/cma-cases/hmv-group-plc-ottakar-s-plc-merger-inquiry-cc

${ }^{37}$ Averitt, N./Lande, R./Nihoul, P., “'Consumer choice' is where we are all going - so let's go together”, Foreword, Concurrences No 2-2011; Averitt, N./Lande, R., “Using the 'Consumer Choice' Approach to Antitrust Law, 74 Antitrust L.J. (2007), pp. 175-264

${ }^{38} \mathrm{COMP} / \mathrm{C}-3 / 37.792$
} 
media player tying decision, the Commission focused on the anticompetitive effect stemming from preventing customers to base their choices on their non-price preferences, hence considering the factors whose consideration would be rendered easier if a consumer choice paradigm were explicitly introduced in competition enforcement. A similar argument is relevant for the Google case where the abusive conduct is connected with an improvement in the quality of a service provided by Google. Similar traits are detected in various $\mathrm{EU}^{39}$ and US cases. ${ }^{40}$ Because the consumer welfare standard encompasses both price and non-price elements, the two standards do not diverge when there is a deterioration of the quality of the post-merger product, even if there is no price increase, ${ }^{41}$ unless the consumer welfare standard is construed narrowly and focuses on price factors.

The growing importance of considering non-price factors like innovation is not recent. There is dearth of caselaw based on network effects, the lock-in effect, the gatekeeper effect, switching costs, and multi-sided markets. But now such analysis requires to factor in a significant increase in the pace of innovation with continuous developments such as open-source software, online ecosystems, scale effects, feedback loops, data, and algorithms. Therefore, competition authorities around the world need to be cognizant of these new trends in order to protect the standards of consumer welfare in a more effective way.

\footnotetext{
${ }^{39}$ France Telecom (C-202/07 P [2009]; T-340/03 [2007]); Wanadoo (COMP/38.223); cf. in detail Nihoul, P., “'Freedom of choice': The Emergence of a powerful Concept in European Competition Law, 05.06.2012, available at http://papers.ssrn.com/sol3/papers.cfm?abstract_id=2077694

${ }^{40}$ Realcomp II (6 ${ }^{\text {th }}$ Circuit Court of Appeals, Realcomp II, Ltd. v. FTC, 2011 WL 1261180)
} 


\section{Innovation in competition enforcement}

Several debates over time have claimed that the US approach towards giving innovation a more prominent place in competition analysis is more proactive than the Commission's take on the matter. ${ }^{42}$ While holding leadership positions at the Antitrust Division of the United States Department of Justice (DoJ), Gilbert and Sunshine initiated a debate about the role of innovation in merger analysis as early as the $1990 \mathrm{~s} .{ }^{43}$ They introduced the concept of 'innovation markets' which would enable competition authorities to measure the impact of a merger in downstream product markets as well as in upstream innovation markets. In their view, the latter approach is necessary to assess the effects of a proposed transaction on innovation in markets where the merging parties are not actual or even potential competitors prior to the merger. ${ }^{44}$ Such analysis ensures that the competition authorities are assessing mergers holistically.

42 DAF/COMP(2017)2 "Competition Issues in Aftermarkets", available at https://one.oecd.org/document/DAF/COMP(2017)2/en/pdf.

${ }^{43}$ Both Richard J. Gilbert and Steven C. Sunshine were formerly Deputy Assistant Attorneys General in the Antitrust Division of the United States Department of Justice.

${ }^{44}$ Gilbert RJ and Sunshine SC, "Incorporating Dynamic Efficiency Concerns in Merger Analysis: The Use of Innovation Markets", Antitrust L.J. 1995, vol. 63, no. 2, (569), 570. 
Innovation has been argued to play a fundamental role in the Commission's goal of increasing growth and investments. ${ }^{45}$ Economic literature has identified two main forms of innovation, product and process innovation. ${ }^{46}$ Product innovation relates to when specific goods or services are introduced in the market for the first time or are significantly improved from the ones pre-existing in the market; with respect to their characteristics or intended uses. Process innovation relates to the implementation of a new or significantly improved production or delivery method. ${ }^{47}$

Although there are many schools of thought on the relationship between innovation and degree of concentration in a market, the two most prominent in recent debate are Aghion's ${ }^{48}$ and Shapiro's ${ }^{49}$. Aghion describes the relationship between competition and innovation (as proxied by the Lerner index and patent activity) as an inverted U shape i.e. for low levels of competition, innovation initially increases as competition becomes more intense; and after reaching its peak, innovation declines as competition intensifies further.

\footnotetext{
45 'PRIORITY Jobs, Growth And Investment Stimulating Investment For The Purpose Of Job Creation' (European Commission, 2017) https://ec.europa.eu/commission/priorities/jobs-growth-and-investment_en

${ }^{46}$ Competition Policy Brief EU Merger Control And Innovation (1st edn, European Commission 2016) $<$ http://ec.europa.eu/competition/publications/cpb/2016/2016_001_en.pdf>

${ }^{47}$ Competition Directorate-General of the European Commission, 'Competition policy brief' (2016)

<http://ec.europa.eu/competition/publications/cpb/2016/2016_001_en.pdf

${ }^{48}$ Aghion et al., Competition and Innovation: An Inverted U Relationship, NBER Working Paper No. 9269, Issued in October 2002

${ }^{49}$ Shapiro C., 'Competition and Innovation: Did Arrow Hit the Bull's Eye?' in J Lerner and S Stern (eds) The Rate and Direction of Inventive Activity Revisited (University of Chicago Press 2012) 361.
} 
The result is that the rate of innovation increases more rapidly than in unlevelled industries and that innovation rates are generally higher for all levels of concentration and competition in markets. The increase in innovative activity will be temporary, until the industry reaches its new steady state. This is predicted to occur when the industry becomes unlevelled (i.e. a single firm has much larger technological capacity than all others).

Shapiro's theory on innovation is based on three main principles. First, markets must be contestable for innovation to flourish. Second, increased appropriability (ability for a firm to capture value from its innovation and ability to protect the competitive advantage associated with it) increases innovation. Third, synergies arising from complementary R\&D assets enhances the ability to innovate. Both Aghion and Shapiro's approaches represent a movement away from a narrow, pipeline-to-product-market approach in merger enforcement. These newer theories are concerned with whether the merger could affect innovation in the industry as a whole, rather than that which is specifically related to the merging parties, and questions the validity of a presumption that mergers reduce innovation.

The Commission has taken onboard the above theories of innovation in its merger enforcement practice as the paper will discuss below. 


\section{II.1 Commission's approach to innovation in merger control}

Innovation is a factor explicitly mentioned in the European Commission Horizontal Merger Guidelines, ${ }^{50}$ as well as the Non-Horizontal Merger Guidelines. ${ }^{51}$ The concept of innovation is difficult to quantify and hence factoring it as a non-price factor in merger assessment becomes tougher for competition regulators. ${ }^{52}$ Proxies that have been used include number of patents, number of new products and R\&D spending. However, the correlation is not necessarily significant as the final products arising from any of these proxies may underestimate the investment on innovation.

In recent years, there seems to be an attempt of explicitly incorporating innovation in merger assessment. There is an ever increasing body of caselaw related to the assessment of the impact of a concentration on innovation. The approach the Commission took in the earlier cases such as the ones in the pharmaceutical sector that we will analyse below,

\footnotetext{
${ }^{50}$ In markets where innovation is an important competitive force, a merger may increase the firms' ability and incentive to bring new innovations to the market and, thereby, the competitive pressure on rivals to innovate in that market. Alternatively, effective competition may be significantly impeded by a merger between two important innovators, for instance between two companies with "pipeline" products related to a specific product market. Similarly, a firm with a relatively small market share may nevertheless be an important competitive force if it has promising pipeline products. Guidelines on the assessment of nonhorizontal mergers under the Council Regulation on the control of concentrations between undertakings [2008] OJ 1 265/6, paragraph 38.

51 The Commission will assess innovation noting that vertical and conglomerate mergers are more likely to create efficiencies than mergers between competitors in the same market.

${ }^{52}$ Ioannis Kokkoris, Howard Shelanski, EU Merger Control: A Legal and Economic Analysis (1st edn, Oxford University Press 2014) para 12.19
} 
illustrates a cautious and gradual attempt to explicitly incorporate innovation concerns as a factor in the assessment. As the experience of the Commission evolved, its approach changed and in more recent cases such as the Dow/Dupont and the Bayer/Monsanto the Commission became bolder. In the earlier cases, the focus of the analysis of innovation was mainly limited to overlap products as well as overlap R\&D pipelines that were closer to commercialisation than is the case in the more recent decisions. Furthermore, in the more recent cases, the Commission expanded from antitrust markets to antitrust innovation spaces, that may involve a group of antitrust product markets that are characterised by similar innovation efforts. Thus, the remedies in the latter cases appear to be more expansive than the ones in the former cases.

In a number of earlier cases in the pharmaceutical sector the Commission was concerned if the merger make the post-merger entity the sole owner of important assets for the innovation in the sector. ${ }^{53}$ In Glaxo Wellcome/ Smithkline Beecham ${ }^{54}$ the Commission argued that the merger may deter any $\mathrm{R} \& \mathrm{D}$ trial by other parties to improve anti-viral medications. The EU Commission concluded that the merger can be cleared as there were similar products in the anti-migraine market being developed by other competitors. The Commission's practice has shown that it will assess innovation and the impact of the merger on innovation even if the R\&D is still in its early stages. In Pfizer/Hospira ${ }^{55}$, and

\footnotetext{
53 Vodafone Airtouch/Mannesmann (Case COMP/M.1795) Commission decision [2003] OJ C 300

${ }^{54}$ Case No COMP/M.1846 - Glaxo Wellcome / Smithkline Beecham

${ }^{55}$ Case No COMP/M7559 PFIZER/ HOSPIRA [2015] EC. The Commission was concerned about future innovations for biosimilar drugs, which are equivalent with the biological pharmaceuticals. The Commission argued that Pfizer would have either delayed or even stopped the development of Samsung Bioepis and only consider Hospira's existing inflimax (co-marketed with Celltrion), or would have left inflimax to Celltrion.
} 
Medtronic/Covidien ${ }^{56}$ the Commission cleared both transactions with divestments as one of the merging companies was in the process of selling a drug, while the other company was in the late-stage of developing potential competing product, and the merger would risk the elimination of the product in development. ${ }^{57}$ In a recent case, Novartis/GlaxoSmithKine's (GSK) oncology business ${ }^{58}$, the Commission assessed all research in development and not just the ones in the later stages of development and thus more likely to be successful. The Commission further raised concerns that GSK has similar pipeline projects with Novartis.

These cases illustrate an interesting path of the Commission's journey to its current approach in the assessment of innovation in concentrations. Interestingly, in a survey on 65 cleared transactions conducted by Haucap and Stiebale, they argued that mergers in the pharmaceutical sectors impede innovation not only between the merged firms but on the non-merging parties. ${ }^{59}$ In the earlier cases (Glaxo Wellcome/ Smithkline Beecham, ${ }^{60}$

\footnotetext{
${ }^{56}$ Case No COMP/M7326 MEDTRONIC/ COVIDIEN [2014]. In the Medtronic/Covidien case, Medtronic was the market leader in the drug-coated balloons market. Covidien had a drug-coated balloon named Stellarex, which was a last stage pipeline product. The Commission argued that innovation in relation to Stellarex would have been prevented.

${ }^{57}$ The divestment related to the product in development

${ }^{58}$ Novartis/GlaxoSmithKline's Oncology Business (Case No COMP/M.7275) [2015].

${ }^{59}$ Justus Haucap, Joel Stiebale, 'Research: Innovation Suffers When Drug Companies Merge', Harvard Business Review, 3 August 2016 https://hbr.org/2016/08/research-innovation-suffers-when-drug-companiesmerge.

${ }^{60}$ Case No COMP/M.1846 - Glaxo Wellcome / Smithkline Beecham
} 
Pfizer/Hospira ${ }^{61}$, and Medtronic/Covidien) the Commission seems to adopt a more limited approach to the assessment of R\&D pipelines and of innovation efforts. In Novartis/GlaxoSmithKine's (GSK) oncology business ${ }^{62}$ the Commission adopted an expanded perspective and a different analysis of the overlap of the merging parties and went beyond the R\&D efforts/overlaps of the parties in the later stages of development, analysing all R\&D efforts of the merging parties.

The Commission's evolving analytical approach to innovation in the pharmaceutical sector became relevant for concentrations in other sectors as well. In Intel/Mc Afee ${ }^{63}$, the Commission was concerned about the fact that the innovation could be affected negatively by the foreclosure, which would have been created by Intel, by complying its central processing units and chipsets solely with McAfee's software service and thus curtailing endpoint security solutions for rivals of McAfee. The merger was cleared after behavioural remedies committing Intel to procure services from competitors of McAfee. The approach the Commission took regarding the impact on innovation resembles its assessment in earlier vertical cases with the important difference that the focus was on the impact of potential foreclosure on innovation.

\footnotetext{
${ }^{61}$ Case No COMP/M7559 PFIZER/ HOSPIRA [2015] EC. The Commission was concerned about future innovations for biosimilar drugs, which are equivalent with the biological pharmaceuticals. The Commission argued that Pfizer would have either delayed or even stopped the development of Samsung Bioepis and only consider Hospira's existing inflimax (co-marketed with Celltrion), or would have left inflimax to Celltrion.

${ }^{62}$ Novartis/GlaxoSmithKline's Oncology Business (Case No COMP/M.7275) [2015].

${ }^{63}$ Case No COMP/ M.5984, Commission decision of 26 January 2011
} 
The Commission in the prohibition decision Deutsche Borse/NYSE, ${ }^{64}$ argued that the concentration would lessen the incentive which the merged entity would have to innovate, inter alia, in technology competition and would give rise to a reduction in the innovation available for customers. In the appeal to the General Court, Deutsche Borse claimed that the Commission's finding that the operation would reduce innovation was 'manifestly incorrect and unsubstantiated' but the General Court rejected those claims. ${ }^{65}$ It added that the fact, that all major derivatives exchanges are operators and developers of trading technology does not call into question the conclusion that the merger would lessen the innovation incentives of the merged entity and would result overall in less innovation being available to customers in those markets. ${ }^{66}$ The Commission's argument follows a standard unilateral effects analysis with innovation as the main theory of harm rather than an adverse impact on price related factors.

In a controversial case, GE/Alstom ${ }^{67}$ the Commission was concerned about reduced innovation and higher prices in the market for a technology vital to responding to climate change. The Commission argued that the merger would bring together two of the three main competitors in the market. This would eliminate a significant innovator, diminish

${ }^{64}$ Deutsche Borse/NYSE Euronext (Case COMP/M.6166) Commission decision [2012] OJ C 440

${ }^{65}$ Case T-175/12 Deutsche Borse AG v European Commission [2015] EU:T:2015:148 para 171 and paras 160-177. the fact, referred to by the applicant, that all major derivatives exchanges around the world are operators and developers of trading technology is not such as to call into question the conclusion that the concentration would lessen the incentive which the merged entity would have to innovate in technology, process and market design in order to respond to those same competitive threats, and would result overall in less innovation being available to customers in those markets.

${ }^{66}$ Case T-175/12 Deutsche Borse AG v European Commission [2015] EU:T:2015:148 para 177.

${ }^{67}$ General Electric/ Alstom (Case COMP/M.7278) Commission decision [2015] OJ C 70 
competitive pressure on other rivals and reduce rival's incentive to invest in innovation. Alstom had to divest parts of the heavy-duty gas turbines business to Ansaldo as a remedy. ${ }^{68}$ Similar to the cases above, the Commission assessed the impact on innovation on particular antitrust markets and required remedies that would prevent this adverse impact on innovation.

The Commission's approach in the Dow/Dupont ${ }^{69}$ transaction followed the Novartis/GlaxoSmithKine's (GSK) oncology business ${ }^{70}$ in that it did not assess the innovation efforts of the parties that were close to commercialisation as in the earlier cases but also the parties' innovation activities that were at a much earlier stage, that of research than that of the development. In addition, the Commission in this case moved from the concept of antitrust markets to that of innovation spaces. This is the first case where we see this new approach of the Commission that also led to extensive remedies in relation to innovation.

\footnotetext{
${ }^{68}$ The parties had to divest products that were likely to be discontinued, as well as existing upgrades, and pipeline technology for a future upgrade of the relevant product. Alstom committed to release a significant share of its long-term servicing agreement for the GT26 turbine, divest its test facilities for its turbines and its $R \& D$ engineers, in order to enhance the viability of the purchaser.

${ }^{69}$ Case M. 7932 Dow/Dupont dated 27.3.2017.

${ }^{70}$ Novartis/GlaxoSmithKline's Oncology Business (Case No COMP/M.7275) [2015].
} 
In Dow/Dupont, ${ }^{71}$ Commissioner Vestager argued that: 'We need to make sure that the proposed merger does not lead to higher prices or less innovation for these products. ${ }^{72}$ In this case, the Commission investigated whether there would be lack of incentives to continue ongoing parallel innovation. Looking at the R\&D pipelines of the parties, the Commission found that the two are competing head-to-head in a number of important herbicide, insecticide and fungicide innovation spaces. After the merger, they would have an incentive to discontinue some of these costly development efforts to avoid duplication. The Commission in Dow/DuPont found specific evidence pointing toward lower incentives and lower ability to innovate post-merger. According to these findings, the merged entity would certainly cut back on R\&D spending which would be a factor against approval of the concentration.

The merger was conditionally cleared with a significant divestment on part of DuPont's existing pesticide business including its research and development organisations and its pipeline projects, along-with both tangible and intangible assets. Such divestment was sought by the Commission in order to enable the purchaser to become a global integrated research and development competitor. ${ }^{73}$ The merger was approved after significant divestments that focused on maintaining the innovation in the market.

\footnotetext{
${ }^{71}$ Case M. 7932 Dow/Dupont dated 27.3.2017.

${ }^{72}$ European Commission - Press release, 'Mergers: Commission opens in-depth investigation into proposed merger between Dow and DuPont' (11 August 2016) http://europa.eu/rapid/press-release_IP-162784_en.htm.

${ }^{73}$ Ibid.
} 
In another case in the highly dynamic agrochemical sector, Bayer/Monsanto ${ }^{74}$ the Commission continued its new approach to the assessment of innovation as a factor of the assessment. The Commission assessed more than 2,000 different product markets and reviewed 2.7 million internal documents and concluded that the transaction would have significantly reduced competition on price and innovation. The Commission focused and analysed extensively the innovation incentives of the parties. The Commission found that the transaction would have eliminated innovation competition on GM and non-GM traits conferring herbicide tolerance or insect resistance. It would also eliminate innovation competition in herbicides and herbicide systems (i.e. herbicide combined with a trait conferring herbicide tolerance to a crop). The Commission concluded that the divestment package the parties offered would enable the purchaser BASF to sustainably replace Bayer's competitive effect in these markets and continue to innovate. Thus, innovation competition would not be adversely affected as a result of the transaction.

We can surmise from the above analysis that the merger enforcement caselaw is clear. The Commission will analyse whether a merger will pose to be a threat to such innovation. When formulating a concise formula of how to assess mergers with substantial innovation effects in any given market, the Commission's observations in Dow/Dupont is worth mentioning. ${ }^{75}$ In this case the Commission noted the following points in relation to its approach on the assessment of innovation:

\footnotetext{
${ }^{74}$ M.8084 Bayer/Monsanto, unreported

${ }^{75}$ Bayer/Monsanto is not published at the time of writing.
} 
i. Innovation effects are required to be assessed post-merger when there is a competitive landscape with only five integrated R\&D players at industry level and even fewer players at the level of individual innovation spaces (e.g. insecticides for a given crop and pest in the Dow/Dupont case);

ii. Consideration of high barriers to entry must be analysed due to the need for global field stations and registration capabilities;

iii. Any direct evidence of the suppression of R\&D efforts post-merger must be factored in;

iv. The strength and closeness of the merging parties in innovation areas must be considered;

v. Overlaps within the R\&D activities of the parties will be considered; as well as

vi. Past evidence on the relationship between concentration and innovation efforts. ${ }^{76}$

Thus, the Commission will assess closely a merger between two innovators that are active in similar pipeline products, and the transaction may eliminate an important competitive force. Remedies in such cases usually aim to introduce new innovative competitor into the market to impose competitive constraints to prevent price increase and preserve innovation. ${ }^{77}$ Even if innovation may not be the sole consideration, it is still an influential additional concern to competition with implications on the design of the remedies. ${ }^{78}$

\footnotetext{
${ }^{76}$ Johannes Laitenberger Director-General for Competition, European Commission, "EU competition law in innovation and digital markets: fairness and the consumer welfare perspective" MLex / Hogan Lovells event Brussels, 10.10.2017, available at http://ec.europa.eu/competition/speeches/text/sp2017_15_en.pdf.

${ }^{77}$ Raphael De Coninck, “Innovation in EU Merger Control: In Need of a Consistent Framework”, (2016) 2(3)

Competition Law \& Policy Debate 41, 43.

${ }^{78}$ Ibid.
} 
The above analysis of the caselaw does illustrate that remedies in innovation cases may seem too onerous or extensive from a static competition point of view. However, innovation goes hand in hand with dynamic competition, thus effective remedies may go beyond the traditional approach towards overlapping assets in particular markets. An effective remedy can extend to group of assets, such as patents, experts, and other tangible and intangible assets. Following the approach of the Commission in the remedies in the Dow/Dupont and the Bayer/Monsanto transactions, the Commission can focus on innovation spaces, which can extend beyond the standard antitrust or innovation markets. An effective remedy can cover not only an actual overlapping process or product (the Research element in R\&D), but also the thinking behind it and the ability to create an overlapping process or product (the Development element in R\&D).

The development of the caselaw discussed above, indicates the gradual advancement and maturity of the Commission's analysis of mergers involving innovation considerations. Mergers involving important innovators in largely concentrated industries with high barriers to entry and with no history of innovation from companies outside the sector, are likely to be problematic from a merger control point of view. Such mergers are likely to lead to an overall reduction in innovation efforts and, to a reduction in the number and quality of new products. In contrast, Colomo ${ }^{79}$ argues that in the current state of EU competition law, there is no way that innovation considerations can be introduced. He adds that the standard of proof needed would be too high, and there is a different field of intellectual property regime that can better address innovation concerns, if innovation concerns may not be easily addressed by administrative action.

\footnotetext{
${ }^{79}$ Pablo Ibanez Colomo, 'Restrictions on innovation in EU Competition Law' (2016) 41(2) ELRev 201, 209
} 
After presenting the relevance and importance of innovation in merger assessment, the paper discusses the role of innovation as a non-price assessment factor in unilateral conduct cases and whether the Commission has taken a different perspective compared to the one in merger control.

This paper discusses below two unilateral conduct cases where the Commission focused on innovation as one of the considerations it took into account in its assessment. These are the Microsoft case and the Google case. As the analysis below will illustrate, the Commission's approach to the assessment of the harm on innovation seems to be elementary compared to its merger practice. This may be due to the lack of experience/precedents in unilateral conduct cases raising significant concerns on innovation but may also be due to the complexity of the relevant sectors and the innovation considerations and complexities that these sectors give rise to.

Furthermore, different sectors create different challenges for competition authorities when they assess innovation. For example, the pharmaceutical sector that has been the main bread and butter type of concentrations where the Commission has assessed innovation raises complicated issues as we saw above, but such issues are likely less diverse in nature compared to a different sector such as software development, online shopping and similar markets. The nature of such sectors is changing at a highly dynamic pace and the challenges can be more diverse than a less dynamically paced but still very innovative sector such as pharmaceuticals. 


\section{II.2 Unilateral Conduct in Innovative Markets}

In unilateral conduct cases the issue of innovation and other price factors is by nature more prevalent where intellectual property issues are at stake. The relationship between competition law and intellectual property rights is not only very close, but a very intricate one. One of the ultimate - indirect - goals of these two areas of law is the same: favouring progress and innovation in any specific industry. The way in which this goal is pursued, however, is radically different. While competition law is aimed at promoting the freedom of competition in the market and, with some exceptions in specific markets, deregulation, the aim of intellectual property law is to protect the IP-right holders and, as a result, limiting competition against them whenever they satisfy specific criteria. Thus, there are instances of conflict between the two. This mainly happens in situations of cumulative innovation and when IP is used strategically in order to exclude competitors and harm consumers. ${ }^{80}$

\footnotetext{
${ }^{80}$ The paper will focus on unilateral practices and will not examine the anticompetitive effects of licensing agreements.
} 
There is extensive caselaw exemplifying some of the above concepts. Such cases relate to abusive conducts such as ${ }^{81}$ refusals to supply ${ }^{82}$ (Commercial Solvents ${ }^{83}$ ), tying ${ }^{84}$ (Hilti $^{85}$,

${ }^{81}$ This list is merely indicative.

${ }^{82}$ On refusal to deal/essential facilities see indicatively: Nagy C. (2007), "Refusal to deal and the doctrine of essential facilities in US and EC competition law: a comparative perspective and a proposal for a workable analytical framework” E.L. Rev., 32(5), 664-685, Carlton D., (2001), “A General Analysis of Exclusionary Conduct and Refusal to Deal - Why Aspen and Kodak Are Misguided," NBER Working Paper No. 8105, www.nber.org/papers/w8105, Chen Z., Ross T. \& Stanbury W.T., (1998) "Refusals to Deal and Aftermarkets" 13 Review of Industrial Organization 131, Doherty B., (2001) "Just What Are Essential Facilities?” 38 CML Rev 397, Jones A., “A Dominant Firm’s Duty to Deal: EC and US Antitrust Law Compared" in Handbook of Research in Transatlantic Antitrust (Philip Marsden, ed. 2006), Lang J.T. (1994), 'Defining Legitimate Competition: Companies' Duties to Supply Competitors and Access to Essential Facilities" 18 Fordham International Law Journal 437, Lao M., (2005) “Aspen Skiing and Trinko: Antitrust Intent and Sacrifice" 73 Antitrust Law Journal 171, OECD, "The Essential Facilities Concept" Background Note, OCDE/GD(96)113, Robinson G, (2002) “On Refusing to Deal with Rivals" 87 Cornell Law Review 1177, Stratakis A., (2006), "Comparative Analysis of the US and EU Approach and Enforcement of the Essential Facilities Doctrine” 27 ECLR 434, Venit J., (2005) “Article 82: The Last Frontier - Fighting Fire with Fire?" 28 Fordham International Law Journal 1157.

${ }^{83}$ Cases 6\&7/73, Instituto Chemioterapico Italiano SpA and Commercial Solvents Corp v Commission (Commercial Solvents) [1974] ECR 223.

${ }^{84}$ On tying and bundling see indicatively: Spector D. (2006), "From harm to competitors to harm to competition: one more effort, please!", Euro CJ, 2(1) Supp (Special issue), 145-162, Kuhn K-U., Stillman R., Caffarra C. (2005) "Economic theories of bundling and their policy implications in abuse cases: an assessment in light of the Microsoft case" Euro CJ, 1(1), 85-121, Ridyard D. (2005), "Tying and bundling - cause for complaint?" ECLR, 26(6), 316-319, Furse M. (2004), “Article 82, Microsoft and bundling, or "The Half Monti"”' Comp. L.J., 3(3), 169-178, Jean Tirole, The Analysis of Tying Cases: A Primer, 1 Comp. Policy Int'l 1 (2005), Bellamy \& Child, European Community Law of Competition, $6^{\text {th }}$ ed., 2008, para 10.119-10.120, Bishop/Walker, The Economics of EC Competition Law, London, Sweet and Maxwell, $2^{\text {nd }}$ edition, 2002, 209, Nalebuff, Bundling, Tying and Portfolio Effects, DTI Economics Paper No.1, February 2003, Edward 
Tetra Pak $\left.I I^{86}\right)$, abuse of intellectual property rights $\left(\right.$ Magill $\left.^{87}\right)$ and vexatious litigation (Promedia ${ }^{88}$ ). Two cases that this paper will discuss are Microsoft and Google as the relevant markets are very dynamic, innovative and the two cases have frequently been

Iacobucci, Tying as quality control : A legal and economic analysis, University of Toronto, Faculty of Law, Law and Economics. Research Paper No. 01-09, http://papers.ssrn.com/abstract=293602, W.S. Bowman, Tying Arrangements and the Leverage Problem, 67 Yale L.R.19 (19-36) (1957), Hylton/Salinger, Tying Law and Policy: A decision-theoretic approach, 69 Antitrust L.J. 469 (486) (2001), Christian Ahlborn/David S. Evans/A. Jorge Padilla, The antitrust economics of tying: a farewell to per se illegality, The Antitrust Bulletin/Spring-Summer 2004, 287 (323), Dennis W. Carlton \& Michael Waldman, The Strategic Use of Tying to Preserve and Create Market Power in Evolving Industries, 33 Rand J. Econ. 194 (2002), José Carbajo, David de Meza, Daniel J. Seidmann, A strategic motivation for commodity bundling, 38 The Journal of Industrial Economics, 283 (1990), Daniel J. Seidmann, Bundling as a facilitating device: A reinterpretation of leverage theory, 58 Economica 491 (1991), Yongmin Chen, Equilibrium Product Bundling, 70 J. Bus. 85 (1997), McAfee, R.P., J. McMillan and M.D. Whinston, Multiproduct Monopoly, Commodity bundling and correlation of values, 104 Q.J.Econ. 371 (1989), Walter J. Adams \& Janet L. Yellen, Commodity Bundling and the Burden of Monopoly, 90 Q.J.Econ. 475 (1976), Richard L. Schmalensee, Gaussian Demand and Commodity Bundling, 57 J. Bus. 211 (1984), Michael A. Salinger, A Graphical Analysis of Bundling, 68 J. Bus. 85 (1995), KN Hylton \& M Salinger, Tying Law and Policy: A Decision - Theoritic Approach, 69 Antitrust L.J., 469 (470-71) (2001), K-U Kühn, R Stillman, C Caffarra, Economic Theories of Bundling and Their Policy Implication in Abuse Cases: An Assessment in Light of the Microsoft Case, CEPR Discussion Paper No. 4756 (2005), Thomas A. Lampert, Evaluating Bundled Discounts, 89 Minn. L. Rev. 1688, 17001705 (2004-2005), Daniel A. Crane, Multiproduct Discounting: A Myth of Nonprice Predation, 72 U. Chi.

L. Rev. 27, (2005) .

${ }^{85}$ Case T-30/89, Hiltiv Commission [1991], ECR II-1439, confirmed C-53/92P, [1994] ECR I-666.

${ }^{86}$ Case T-83/91, Tetra Pak Rausing SA v Commission (Tetra Pak II), [1994] ECR II-755.

${ }^{87}$ Magill TV Guide [1989] OJ L78/43.

${ }^{88}$ Case T-111/96, ITT Promedia NV v Commission (Promedia), [1998] ECR II-2937. 
juxtaposed against one another in relation to the approach the Commission took especially in relation to innovation and non-price assessment factors more generally.

\section{II.2.A The Microsoft Case}

In the seminal Microsoft interoperability case, ${ }^{89}$ Microsoft refused to give Sun the information and technology necessary to allow its work group server operating systems to interoperate with the Windows client PC operating system. Microsoft's refusal risked eliminating competition for work group server operating systems because the refused input was indispensable for competitors operating in that market. The Commission argued that if competitors had access to the refused information, they would be able to provide new and enhanced products to the consumer. These circumstances of an exceptional nature led to the conclusion that Microsoft's refusal constituted an abuse of a dominant position incompatible with Article 102, unless it was objectively justified. In another Microsoft case, the Commission had launched in 2000 an ex officio investigation into Microsoft's incorporation of Windows Media Player into its PC operating system product. The Commission concluded that consumers had no choice but to obtain Windows with Windows Media Player and as a remedy Microsoft needed to provide a version of Windows which does not include Windows Media Player. ${ }^{90}$ The Commission noted ${ }^{91}$ that consumers

\footnotetext{
${ }^{89}$ Microsoft [2007] OJ L 32/23, Microsoft Corp. v Commission, T-201/04 R, [2004] ECR II-4463, Microsoft Corp. v Commission T-201/04, 17/09/2007

${ }^{90}$ Banasevic N., Huby J., Pena Castellot M., Sitar O., and Piffaut H., Commission adopts Decision in the Microsoft case, Competition Policy Newsletter, Number 2, 2004.

${ }^{91}$ Paragraph 832
} 
are harmed because Microsoft's conduct undermines 'the structure of competition in media players which is liable to result in deterrence of innovation and eventual reduction in choice of competing media players' ${ }^{92}$

Bellis notes that the Commission's attempts to defend its theories should be of serious concern to any company innovating in high- technology products who wish to improve existing features or add new features to successive versions of its products on a uniform basis. ${ }^{93}$ Banasevic et al, argued that customers will prefer using Windows Media Player, since a wider array of complementary software and content will be available compared to other competing products due to the fact that the underlying software where the Media Player will operate is also part of the same ecosystem. ${ }^{94}$ They add that this fact seriously undermines the competitive process in the media player market to the detriment of innovation and the consumer, and has spill-over effects on competition in other markets. ${ }^{95}$

\footnotetext{
${ }^{92}$ In relation to this tying abuse, the General Court added a new requirement to the tying abuse criteria with its Microsoft decision, arguing that the dominant undertaking is engaged in abusive tying when it does not give to consumers a choice to obtain the tying product without the tied product.

${ }^{93}$ Jean-François Bellis has represented Microsoft throughout the Commission's administrative proceedings leading to the Microsoft Decision and in the Commission's appeal against that Decision, and made the oral pleading on behalf of Microsoft with regard to the tying part of the case. Bellis J.F., The Commission's Microsoft Tying Case: Implications for Innovation Throughout the High-Technology Sector, http://www.lawprofessors.typepad.com/antitrustprof_blog/files/Bellis.pdf

${ }^{94}$ Banasevic N., Huby J., Pena Castellot M., Sitar O., and Piffaut H., Commission adopts Decision in the Microsoft case, Competition Policy Newsletter, Number 2, 2004.

${ }^{95}$ Banasevic N., Huby J., Pena Castellot M., Sitar O., and Piffaut H., Commission adopts Decision in the Microsoft case, Competition Policy Newsletter, Number 2, 2004.
} 


\section{II.2.B The Google Shopping case in the EU}

The Google shopping case is one of the controversial cases, or possibly the most controversial one, in unilateral conduct enforcement to date. The fine is the highest ever after the one on the Google Android case for an abusive conduct. The relevant market is a highly innovative one where price factors play limited or no role, but non-price factors such as choice and innovation assume a significant role in the Commission's assessment of the abusive conduct.

In the Google case, ${ }^{96}$ the Commission noted that Google's conduct can lead to less innovation. However, it assesses this impact in only three paragraphs out of 755 and mentions the word innovation and its derivative words a total of seven times. Thus, the Commission's analysis on innovation seems to be rather short especially considering the importance the Commission and Commissioner Vestager has put on innovation. ${ }^{97}$

The Commission identified a number of practices that could constitute an infringement by Google of Art. 102 TFEU. ${ }^{98}$ Its chief concern lay in the potential effects the prominent display within Google's web search results, of Google's own specialised web search

\footnotetext{
${ }^{96}$ Case AT.39740 Google Search (Shopping). The research on the Google case has been kindly supported by Google Inc.

${ }^{97}$ Interestingly, the word innovation and its derivatives are mentioned 6 times in the press release related to the decision.

${ }^{98}$ Commission seeks feedback on commitments offered by Google Search (Shopping) to address competition concerns - questions and answers; See European Commission, MEMO 25 April 2013, available at < http//europa.eu/rapid/press-release_MEMO-13-383_en.htm >.
} 
services as compared to competing specialised web search services could have. ${ }^{99}$ The Commission expressed its concerns as to whether this practice could result in online traffic being diverted away from Google's competitors in specialised search towards Google's own specialised search services. This could ultimately harm consumers, as according to the Commission's reasoning, on the one hand the latter are not aware of the promotion of Google's services within the search results; and on the other hand, competitors' results that are potentially as relevant are significantly less visible and even sometimes not directly visible to users, and hence more difficult for the user to find, 'for instance because the user has to scroll down the screen to see them or has to go to a subsequent search results web page. ${ }^{100}$

Consumer harm would lie according to the Commission in the reduction of the ability of consumers to find a potentially more relevant choice of specialised search services. ${ }^{101}$ Furthermore, the Commission found that Google's conduct has a negative impact on consumers and innovation, in the sense that 'users do not necessarily see the most relevant

\footnotetext{
99 The Commission thus focused on services allowing users to search for specific categories of information such as restaurants, hotels or products. See European Commission, MEMO 25 April 2013, available at $<$ http//europa.eu/rapid/press-release_MEMO-13-383_en.htm >.

100 See European Commission, ibid.

101 The Commission identified as further potentially abusive practices the use by Google without consent of original content from third party web sites in its own specialised web search services; the fact that Google engaged in agreements that obliged third party web sites to obtain all or most of their online search advertisements from Google; as well as the imposition by Google of contractual restrictions on the transferability of online search advertising campaigns to rival search advertising platforms and the management of such campaigns across Google's Adwords and rival search advertising platforms. See European Commission, ibid.
} 
comparison shopping results in response to their queries, and that incentives to innovate from rivals are lowered as they know that however good their product, they will not benefit from the same prominence as Google's product.' ${ }^{102}$ The Commission further argued that the conduct which was foreclosing competing comparison shopping services, may lead to higher fees for merchants, higher prices for consumers, and less innovation.

Thus, the Commission noted that Google's conduct could cause consumer harm by means of the reduction of choice for consumers as well as by stifling innovation in the fields of specialised search services and online search advertising. They accordingly asked for - and this is largely reflected in the Commission's statement - Google to 'treat its own comparison shopping service and those of rivals in the same way'. ${ }^{103}$

Juxtaposing the Microsoft and Google case, in the former, there was a clear reduction of quality - detrimental to consumers - upon which the Courts relied to hold that there was a negative impact on consumer welfare and thus (in conjunction with foreclosure of competitors) led to a finding of abusive tying. Furthermore, the impact of Microsoft's conduct on competitors would also include the harm on their innovation drive. This requirement is certainly not fulfilled in the Google case which we will discuss below as consumers act freely in the market and are not obliged or penalized in any way when choosing the vertical search engine of their preference. In the Google case, there is no argument in relation to deterioration of the quality of services provided by Google but on the contrary the inclusion of the new format has provided better services for customers in

\footnotetext{
102 See European Commission, MEMO 15 April 2015, ibid.

103 "Antitrust: Commission sends Statement of Objections to Google on comparison shopping service"; See European Commission, MEMO 15 April 2015, ibid.
} 
the primary market. A similar argument of product improvement was made in the UK Streetmap case, ${ }^{104}$ in a similar factual context to the Commission's Google shopping case.

\section{II.2.C How to balance unilateral conduct enforcement with the dominant undertaking's innovation drive?}

In assessing a dominant firm's conduct it is important to explore not only the existence of a link between the conduct of the dominant company and the anticompetitive effects but also the characteristics that such a link should bear for the dominant undertaking's behaviour to be considered as abusive. When a behaviour is established as procompetitive in the primary market, meaning that it benefits the consumers and leads to a more efficient competitive process then the assessment of any anticompetitive effects of this very behaviour to a relevant market need to be balanced. In case a link is not proved to the adequate degree, it is highly possible that a dominant company heavily investing in innovation and providing quality services in the primary market is condemned for the results of its success on the competitors of a secondary market. Such an approach comes also in conflict with the Commission's own approach, which acknowledges the right of all companies to compete fiercely on the market if this competition is ultimately beneficial for consumers. ${ }^{105}$ In the Commission's own words in its Guidelines a dominant undertaking is allowed to compete on the merits and 'in doing so (the Commission) is mindful that that

\footnotetext{
${ }^{104}$ The presentation of the thumbnail map introduced by Google was seen as a technical efficiency that leads to superior results for the user on the SERP and counter-balanced the exclusionary effect.

${ }^{105}$ Peeperkorn and Viertio, Implementing an effects-based approach to Article 82, Competition Policy Newsletter, No 1, 2009, 17.
} 
what really matters is protecting an effective competitive process and not simply protecting competitors. This may well mean that competitors who deliver less to consumers in terms of price, choice, quality and innovation will leave the market.' 106

Companies like Google, Yahoo, Microsoft and others that create search engines must have the freedom to make strategic choices about the design of their services. Such freedom is inconsistent with an expansive principle of search neutrality, ${ }^{107}$ but it is indispensable for innovation in the search engine market. ${ }^{108}$ Search neutrality is like perfect competition in economic theory. It doesn't exist in practice! 'Search neutrality' would likely impede the natural evolution of search engines and constrain innovation. ${ }^{109}$ The most important consequence of search neutrality is that by making search engine results uniform, competitors would no longer have an incentive to innovate by investing in enhancing consumers' value. ${ }^{110}$ Manne and Wright argue that 'search neutrality', in its attempt to achieve greater uniformity across search engines, reduces the incentive to engage in that

\footnotetext{
${ }^{106}$ Communication from the Commission, Guidance on the Commission's enforcement priorities in applying Article 82 of the EC Treaty to abusive exclusionary conduct by dominant undertakings para. 6 .

${ }^{107}$ Crane D., Search neutrality and referral dominance, Jnl of Competition Law \& Economics (2012) 8 (3) $459-468$

${ }^{108}$ Crane D., Search neutrality and referral dominance, Jnl of Competition Law \& Economics (2012) 8 (3) $459-468$.

${ }^{109}$ Lao M., Search, Essential Facilities, and the Antitrust Duty to Deal Northwestern Journal of Technology and Intellectual Property, vol 11, issue 5.

110 Manne G., Wright J., If Search Neutrality is the Answer, What's the Question, http//ssrn.com/abstract=1807951.
} 
form of competition.' ${ }^{111}$ Product design choices that can be proved to aim at reducing competition and quality justify competition authority intervention.

According to Bork and Sidak, Google's practices in search constitute a product improvement, which 'adds value to Google search from the perspective of both consumers and advertisers [whereas] Google's critics have attempted to cast this innovation as a form of foreclosure'. ${ }^{112}$ This product improvement element is not prevalent in the Microsoft case but is one of the main arguments Mr Justice Roth considered in the Streetmap case. ${ }^{113}$ The

111 Manne G., Wright J., If Search Neutrality is the Answer, What's the Question, $\underline{\mathrm{http} / / \mathrm{ssrn} . \mathrm{com} / \mathrm{abstract}=1807951}, 46$.

112 Bork R., Sidak G., What does the Chicago school teach about internet search and the antitrust treatment of Google? Jnl of Competition Law \& Economics (2012) 8 (4) 663-700. They argue, that 'search engines epitomize dynamic competition the virtuous cycle in which innovation drives competition, which further drives consumer-welfare-enhancing innovation.' They add that antitrust intervention that mitigates Google's innovation drive would harm consumers as a result of lower quality products and services.

${ }^{113}$ Streetmap EU Ltd v Google Inc. \& Ors [2016] EWHC 253 (Ch) (12 February 2016). This case before the UK High Court bears similarities to the European Commission case and provides a useful exposition of competition assessment that pertains to the Commission case. The facts in Streetmap consider the introduction by Google of a thumbnail map in place of the previous clickable shortcut link in geographical search queries, aiming to enhance the online user's experience while in the comparison shopping case they have to do with the presentation of the Shopping Unit on Google's general search page with directly monetised listings from third-party sites which direct the user to the merchant's website compared to the previous version of one general link to the shopping website. The presentation of the thumbnail map introduced by Google was seen as a technical efficiency that leads to superior results for the user on the SERP and counter-balanced the exclusionary effect. 
FTC noted in relation with its investigation ${ }^{114}$ that 'while Google's prominent display of its own vertical search results on its search results page had the effect in some cases of pushing other results 'below the fold,' the evidence suggests that Google's primary goal in introducing this content was to quickly answer, and better satisfy, its users' search queries by providing directly relevant information. ${ }^{115}$ It should be emphasize, that by protecting less efficient competitors, there is an unavoidable risk of protecting competitors rather than competition itself. ${ }^{116}$

The element of product or process innovation leading to respective improvements needs to be considered by competition authorities in the assessment of abusive unilateral conducts. That will allow the authorities to take a proportionate approach towards enforcement, one that will ensure a careful balance and proportionality between a penalty that will deter anticompetitive conducts and one that will adversely affect innovation incentives. It should be noted, that the penalty is not constrained to monetary figures but also and quite likely

\footnotetext{
${ }^{114}$ Statement of the Federal Trade Commission Regarding Google's Search Practices In the Matter of Google Inc. FTC File Number 111-0163 January 3, 2013, https//www.ftc.gov/sites/default/files/documents/public_statements/statement-commission-regardinggoogles-search-practices/130103brillgooglesearchstmt.pdf, 2 .

115 Thus, there was a quality in the improvement of the service. Statement of the Federal Trade Commission Regarding Google's Search Practices In the Matter of Google Inc. FTC File Number 111-0163 January 3, 2013, https//www.ftc.gov/sites/default/files/documents/public_statements/statement-commission-regardinggoogles-search-practices/130103brillgooglesearchstmt.pdf, 2. "[The] FTC concluded that the introduction of Universal Search as well as additional changes made to Google's search algorithms - even those that may have had the effect of harming individual competitors - could be plausibly justified as innovations that improved Google's product and the experience of its users." http//www.ftc.gov/opa/2013/01/google.shtm ${ }^{116}$ O' Donoghue R., and Padilla J., The Law and Economics of Article 82 EC (Hart Publishing 2006).
} 
more importantly to the changes in the business models that remedies in unilateral conduct cases frequently entail. What the table above does not show is the impact of the remedy on the profitability of the company and more importantly on the business model that has given rise to the innovative products/services. The estimates vary depending on the company, the maturity of the sector, the demand trends but we can certainly argue that direct or indirect intervention by competition enforcement in the modus operandi of companies in an innovative and dynamic sector needs to be done not only with caution but also with care, in order to strike the appropriate balance between welcomed and necessary enforcement against anticompetitive conducts and the potential knock on impact on the operation of the company and its innovation incentives.

The previous Commissioner for Competition Neelie Kroes has stated, regarding the focus of competition enforcement, that 'whether we are looking at the actions of dominant companies, breaking up cartels, vetting mergers, or approving State aid--the potential harm to consumers is at the heart of what we do. We are applying this 'consumer welfare standard' through better use of economic analysis in our work. ${ }^{117}$ It is clear that consumer welfare is placed at the heart of competition enforcement. It is essential to protect consumers from negative effects resulting from insufficiently competitive market structures and anti-competitive business behavior. Foreclosure or harm to competitors is relevant only if this implies harm to consumers through the loss of at least equally efficient or innovative competitors. ${ }^{118}$

\footnotetext{
117 Speech of the Competition Commissioner Neelie Kroes of November 16, 2006 at the Fordham Corporate Law Institute, accessible at http//europa.eu/rapid/pressReleasesAction.do?reference=SPEECH/06/691

118 Kellerbauer M., The Commission's new enforcement priorities in applying article 82 EC to dominant companies' exclusionary conduct a shift towards a more economic approach? ECLR 2010, 31(5), 175-186.
} 
In the context of a unilateral conduct case, what the Commission should assess in detail is whether the harm on some equally efficient or innovative competitors is counter-balanced by the benefits consumers have received from the conduct of the dominant company. A similar approach of assessing the beneficial impact of a conduct to consumers was followed by Mr Justice Roth in the Streetmap case. A product improvement is expected to affect competitors, which are not able to provide an equally efficient service or a good alternative. Therefore, before condemning a conduct as exclusionary a detailed assessment of the procompetitive effects of the conduct should be made in unilateral conduct cases.

EU and US competition authorities both consider dynamic efficiency as a key means of maximizing consumer welfare and achieving their policy objectives. ${ }^{119}$ We should be very cautious in attempting to curtail innovation in industries that through innovation enhance consumer welfare.

\footnotetext{
${ }^{119}$ See speech by G.F. Masoudi, Deputy Assistant Attorney General, DOJ Antitrust Division, Efficiency in analysis of antitrust, standard setting, and intellectual property 18 January 2007, Brussels, Belgium where he stated "Static efficiency is a powerful force for increasing consumer welfare, but an even greater driver of consumer welfare is dynamic efficiency, which results from entirely new ways of doing business. Economists now recognize that the gains from dynamic efficiency, also called "leapfrog" competition, can far outstrip the gains from incremental static improvements. It follows that policymakers should pay particular attention to the impact of laws and enforcement decisions on dynamic efficiency. Intellectual property laws are aimed directly at encouraging dynamic efficiency." The European Commission's commitment to encouraging innovation through competition law enforcement is also illustrated by the speech by Lowe, Director General of DG Competition, European Commission 'Innovation and the Regulation of Dominant Firms', 23 September 2008, Georgetown University, Washington D.C. In Galloway J., Driving Innovation a case for targeted competition policy in dynamic markets, http//ssrn.com/abstract=1763676.
} 
In such markets incumbents do not compete for the market but compete for and on innovation. They compete for the next status quo changing invention, the next 'CD', the next 'search engine', the next 'platform market'. The incumbents are in a continuous, selfreinforcing innovation and creativity drive. In dynamic and innovative industries, certain competitors may be harmed but that fact does not change that consumers benefit from this innovation drive and its spillovers and would be disproportionate to chastise the innovative firm's efforts for harm that competitors may have had, unless a careful assessment is made of the nature of the harmed competitors as well as of the resulting benefits of innovation on consumers.

\section{Is there any impact of competition enforcement on innovation drive}

Competition authorities should be cautious in order to distinguish between harmful, anticompetitive exclusion from 'innovation exclusion' that can also be as a result of undistorted competition on the merits that is driven and expressed through continuous R\&D. Competition authorities must aim to clarify whether a dominant firm's practice, which may at times be considered by the competitors to exercise a detrimental effect on them, is the result of a quality improvement which would be beneficial for consumers and consumer welfare, or rather a deliberate attempt by the dominant firm to harm and exclude its rivals. ${ }^{120}$ In addition, a balancing act between the ensuing penalties and the impact on

\footnotetext{
${ }^{120}$ Cf. Statement of the Federal Trade Commission Regarding Google's Search Practices, ibid., p2 et seq.; see also Marina Lao, Search, Essential Facilities and the Antitrust Duty to Deal, Northwestern Journal of Technology and Intellectual Property, Vol. 11 (2013), No. 5, 276; Ammori, Marvin and Pelican, Luke, Proposed Remedies for Search Bias 'Search Neutrality' and Other Proposals in the Google Inquiry (May 14,

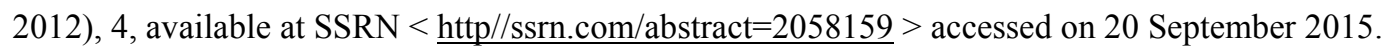


innovation is also appropriate and necessary to prevent mid to long term adverse consequences in the dynamic development of markets.

Imposing a burden on a dominant company in relation to its innovation drive risks stifling innovation and harming consumers. In Microsoft, the Commission's officials do emphasize that the Commission did not merely reject Microsoft's justifications for the conduct, and assessed the impact of the remedy of the obligation to supply on Microsoft's incentives to innovate. ${ }^{121}$ Thus, the remedy in the Commission's view did not risk the innovation incentives of Microsoft. ${ }^{122}$ Although it is not straightforward to test the above assertion of the Commission, we present below in tabular and graphical format the investment of Microsoft on R\&D between 2002 and 2018. Interestingly the R\&D investment was

${ }^{121}$ First, the Commission concluded that an order to supply the relevant information could not lead to the cloning of Microsoft's product, not least because the interoperability information relates to interface specifications as opposed to source code. Second, the Commission took account of the fact that disclosure of interoperability information was commonplace in the industry. Third, the Commission drew inspiration from the IBM undertaking and from the 1991 Software Directive, which strikes a balance between interoperability and copyright in restricting in specific circumstances the exercise of copyright over software (including exercise by non-dominant undertakings) in favour of interoperability, thereby stressing the importance of interoperability in the software industry in order to enhance competition and innovation. Banasevic N., Huby J., Pena Castellot M., Sitar O., and Piffaut H., Commission adopts Decision in the Microsoft case, Competition Policy Newsletter, Number 2, 2004.

${ }^{122}$ Microsoft's innovation drive in the web browser market had slowed down once the Internet Explorer became dominant.... because Internet Explorer was so dominant, Microsoft had little incentive to update and improve it. So, in the end, other - more innovative - browsers like Opera, Safari, Firefox and eventually Google Chrome appeared. In comparison with these newcomers, IE looked increasingly tired and impoverished, the software equivalent of a former heavyweight champion grown fat and arthritic." Netscape: the web browser that came back to haunt Microsoft, Naughton J., The Guardian, https://gu.com/p/46nq4/sbl 
increasing between 2002 and 2004 and in 2005 it fell to levels lower than 2002 and it took until 2008 to surpass the 2004 levels of R\&D investment.

\begin{tabular}{|c|c|}
\hline Year & $\begin{array}{l}\text { Microsoft investment on R\&D } \\
\text { in million U.S. dollars }{ }^{123}\end{array}$ \\
\hline 2002 & 6,299 \\
\hline 2003 & 6,595 \\
\hline 2004 & 7,735 \\
\hline 2005 & 6,097 \\
\hline 2006 & 6,584 \\
\hline 2007 & 7,121 \\
\hline 2008 & 8,164 \\
\hline 2009 & 9,010 \\
\hline 2010 & 8,714 \\
\hline 2011 & 9,043 \\
\hline 2012 & 9,811 \\
\hline 2013 & 10,411 \\
\hline 2014 & 11,381 \\
\hline 2015 & 12,046 \\
\hline 2016 & 11,988 \\
\hline 2017 & 13,037 \\
\hline 2018 & 14,726 \\
\hline
\end{tabular}

\footnotetext{
${ }^{123}$ https://www.statista.com/statistics/267806/expenditure-on-research-and-development-by-the-microsoftcorporation/
} 


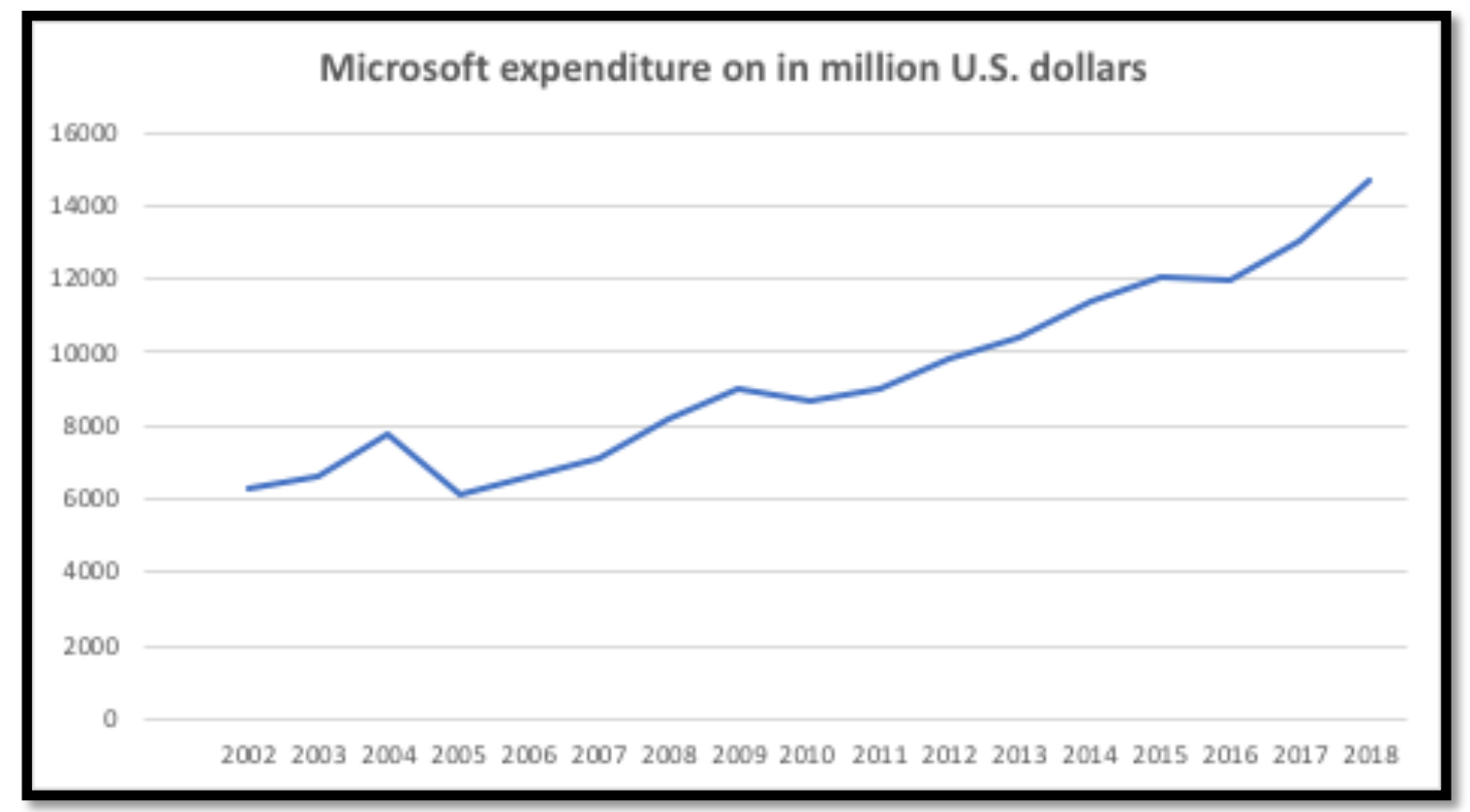

We are not advocating that the decrease in the R\&D investment was solely due to the adverse impact on innovation incentives as a result of the decision but the timing of the change in the increasing trend on $R \& D$ investment prior to the Commission's decision is worth noting.

As the table below illustrates, companies in dynamic sectors invest significant amounts in R\&D. The table ${ }^{124}$ focuses on some of the infamous European Commission unilateral conduct decisions and shows the fines that have been imposed on some major innovative companies that have been found by the European Commission to breach unilateral conduct rules. What is noteworthy is the amount of the fine not as a proportion of the dominant firm's revenues but as a proportion of the investment of the dominant company on R\&D.

\footnotetext{
124 Some data come from Schrepel T., The European Commission Is Undermining R\&D and Innovation: Here's How to Change It ICLE Antitrust \& Consumer Protection Research Program Issue Brief 2018-2. The currency conversion has been done at current exchange rates.
} 


\begin{tabular}{|c|c|c|c|c|c|}
\hline Company & Revenues & $\begin{array}{l}\text { Investment } \\
\text { in R\&D }\end{array}$ & Fine & $\begin{array}{l}\text { Fine as a } \\
\text { proportion }\end{array}$ & $\begin{array}{l}\text { Fine as a } \\
\text { proportion }\end{array}$ \\
\hline & & & & $\begin{array}{l}\text { of } \\
\text { Revenues }\end{array}$ & $\begin{array}{l}\text { of } \quad \text { R\&D } \\
\text { investment }\end{array}$ \\
\hline $\begin{array}{l}\text { Google } \\
\text { (Alphabet) } \\
(2018,2017)\end{array}$ & $\begin{array}{l}\text { USD } 111 \\
\text { billion }\end{array}$ & $\begin{array}{l}\text { USD } 16.7 \\
\text { billion }\end{array}$ & $\begin{array}{l}\text { USD } 7.7 \\
\text { billion } \\
\text { (Google } \\
\text { Shopping } \\
\text { case USD } \\
2.7 \text { billion } \\
\text { and } \\
\text { Google } \\
\text { Android } \\
\text { case USD } \\
5 \text { billion) }\end{array}$ & $\begin{array}{l}2.4 \% \text { for } \\
\text { the Google } \\
\text { Shopping } \\
\text { case and } \\
4.5 \% \text { for } \\
\text { the Google } \\
\text { Android } \\
\text { case }\end{array}$ & $\begin{array}{l}46.1 \% \text { (both } \\
\text { cases } \\
\text { cumulatively) }\end{array}$ \\
\hline $\begin{array}{l}\text { Qualcomm } \\
\text { (2015) }\end{array}$ & $\begin{array}{l}\text { USD } 22.3 \\
\text { billion }\end{array}$ & $\begin{array}{l}\text { USD } 5.15 \\
\text { billion } \\
(2017)\end{array}$ & $\begin{array}{l}\text { USD } 1.1 \\
\text { billion }\end{array}$ & $4.9 \%$ & $21.4 \%$ \\
\hline Intel (2009) & $\begin{array}{l}\text { USD } 29.8 \\
\text { billion }\end{array}$ & $\begin{array}{l}\text { USD } 6.57 \\
\text { billion }\end{array}$ & $\begin{array}{l}\text { USD } 1.17 \\
\text { billion }\end{array}$ & $3.9 \%$ & $17.8 \%$ \\
\hline $\begin{array}{l}\text { Prokent/Tomra } \\
\text { (2006) }\end{array}$ & $\begin{array}{l}\text { USD } 390 \\
\text { million }\end{array}$ & $\begin{array}{l}\text { USD } 15.8 \\
\text { million }\end{array}$ & $\begin{array}{l}\text { USD } 27.8 \\
\text { million }\end{array}$ & $7.1 \%$ & $176 \%$ \\
\hline
\end{tabular}




\begin{tabular}{|c|c|c|c|c|c|}
\hline $\begin{array}{l}\text { Microsoft } \\
(2005)^{125}\end{array}$ & $\begin{array}{l}\text { USD } 36.8 \\
\text { billion }\end{array}$ & $\begin{array}{l}\text { USD } 7.7 \\
\text { billion }\end{array}$ & $\begin{array}{l}\text { USD } 0.6 \\
\text { billion }\end{array}$ & $0.17 \%$ & $7.8 \%$ \\
\hline Table 2 & & & & & \\
\hline
\end{tabular}

Tomra is by far the prominent example where the fine was almost twice the amount spent on R\&D. In the Google cases, the combined fine for both Shopping and Android cases was $46 \%$ of the $R \& D$ investment. In the Google Android case, the fine itself is irrelevant as it amounts to 43 days of operating cash flow (Q4 2017) and 4\% of the cash balance that is on hand. ${ }^{126}$ However, when comparing the fine with the investment on $R \& D^{127}$ the picture is somewhat bleaker as the fine in the Android case amounts to $30 \%$ of the investment on R\&D. Google's fines as a proportion of R\&D, were followed by Qualcomm with $21.4 \%$, Intel with $17.8 \%$ and Microsoft with the fine being equal to $7.8 \%$ of the investment on R\&D.

The graph below illustrates the fines in the above cases as a percentage of the revenues of the dominant companies. The maximum fine can be up to $10 \%$ of the annual worldwide turnover of the dominant undertaking. The two cases against Google have a cumulative fine that is equal to $2.4 \%$ (for Google shopping) and $4.5 \%$ (for the Android case) of

125 https://www.statista.com/statistics/267806/expenditure-on-research-and-development-by-the-microsoftcorporation/

126 https://www.forbes.com/sites/richardwindsoreurope/2018/07/18/eu-fails-to-demand-the-one-remedyfrom-google-that-could-make-a-difference/\#75182de47dac

${ }^{127}$ See table 2 of the paper 
Google's annual worldwide turnover. Tomra leads the table with the fine being equal to $7.1 \%$ of annual worldwide turnover.

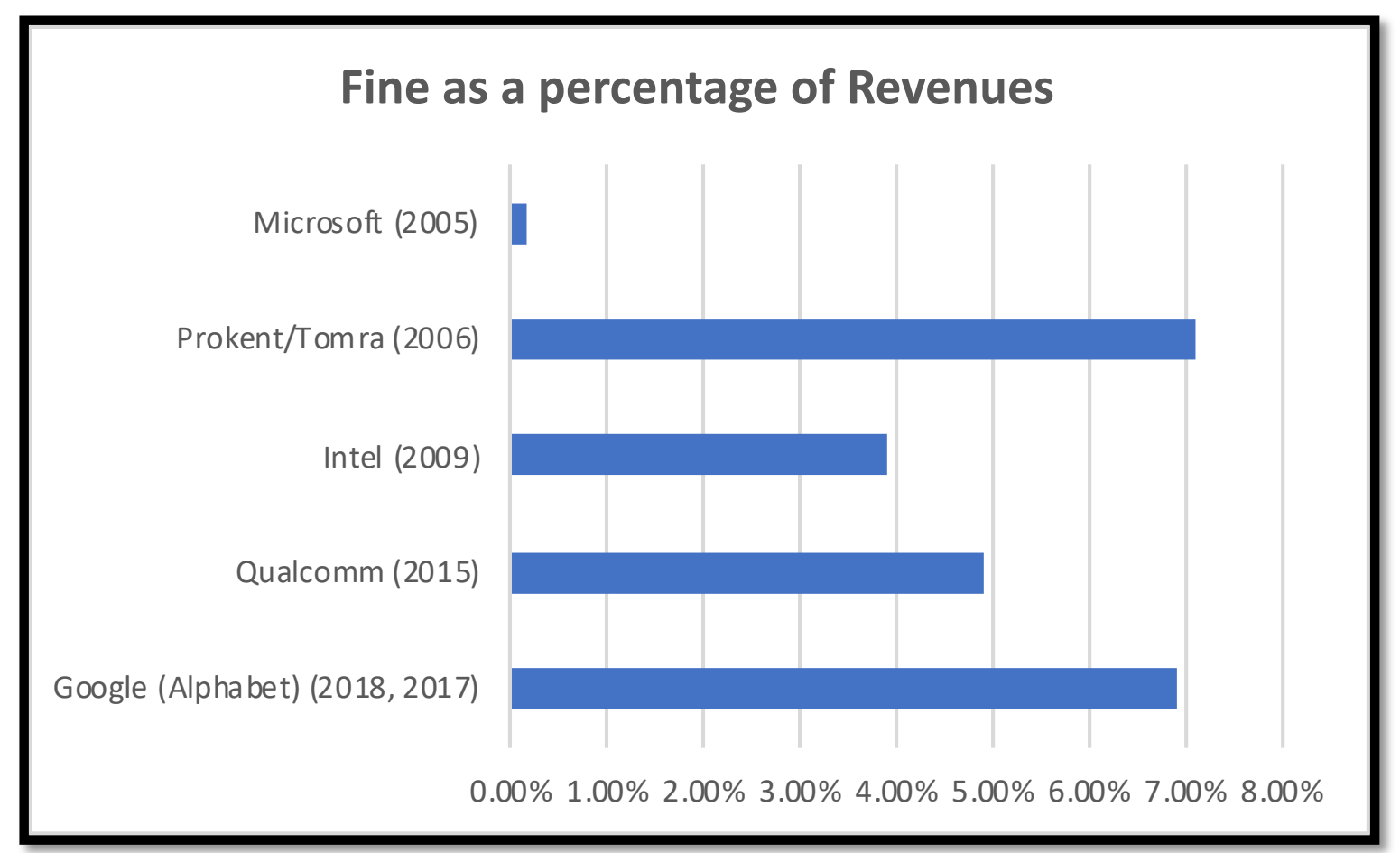

The following graph shows the fines as a percentage of the $R \& D$ investment of the dominant companies. Tomra and Google lead the table. 


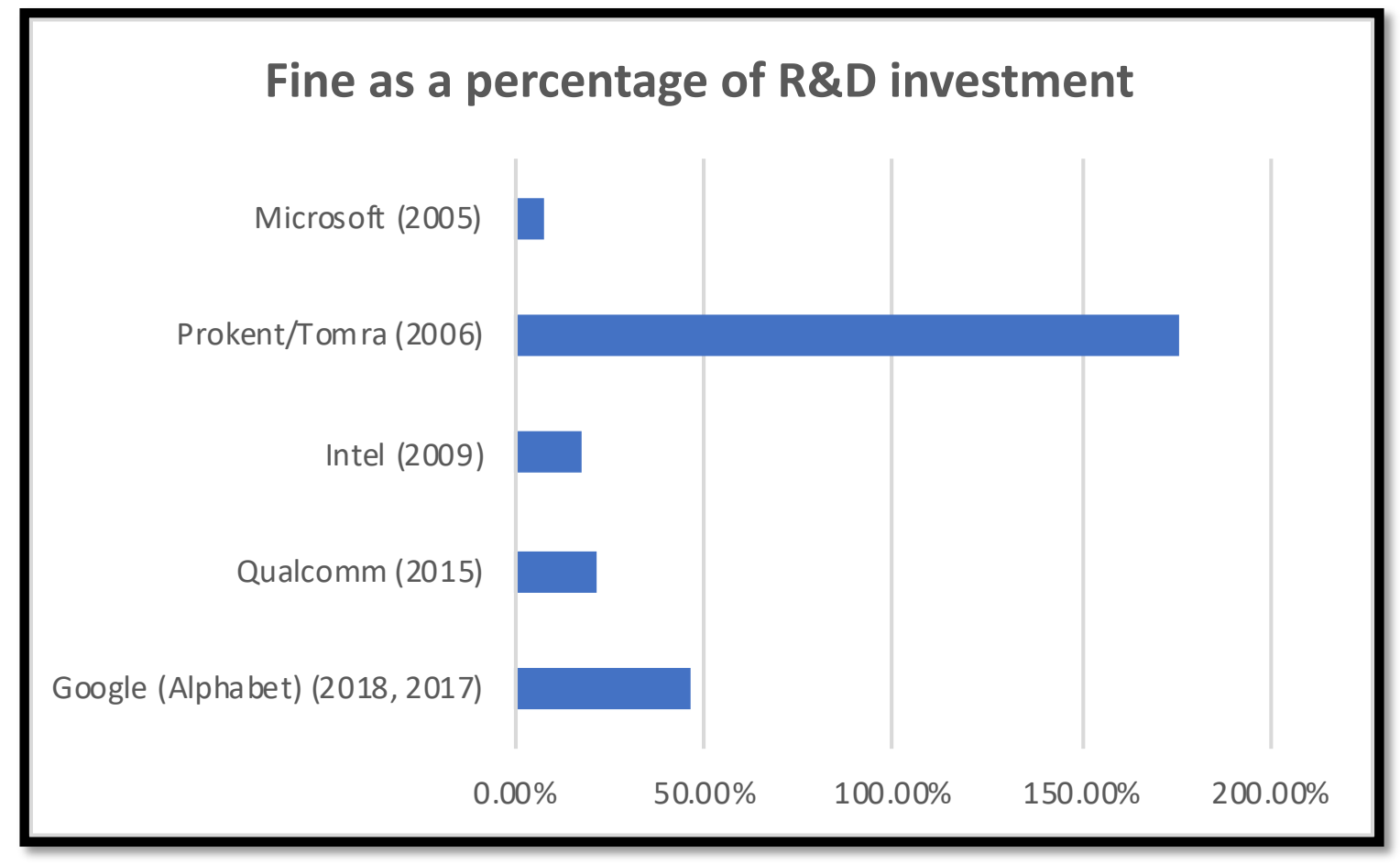

The following two graphs show the fines and the investment on R\&D in a comparative way between the cases. Google tops the ranking having at least double the amount of fines compared to all the other cases in the analysis, and almost equal amount of investment on R\&D. 

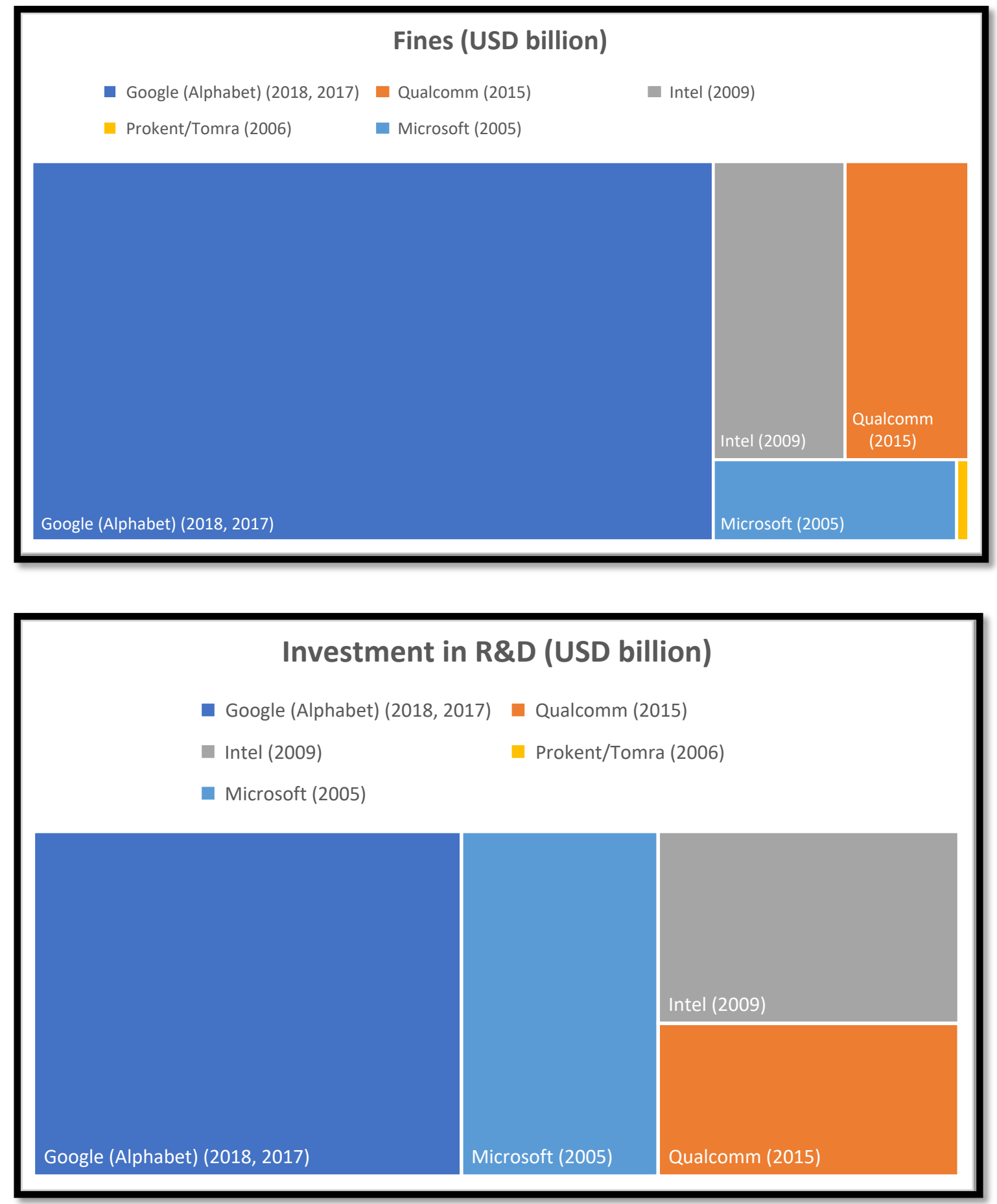
Observing the above graphs makes it obvious that fines may have a significant impact on the R\&D efforts of companies. This can be one of the many reasons why a competition authority must avoid Type I errors ${ }^{128}$ in unilateral conduct enforcement. However, as long as the fines are imposed for anticompetitive practices arising from $R \& D$ efforts fines that account for a high proportion of the R\&D spend are welcome and well justified.

\section{Conclusion}

In dynamic and rapidly-changing industries involving a high level and pace of innovation, where technologies and products are generally short-lived, there is a need to follow a more flexible and holistic competition assessment, considering multiple variables such as R\&D investment, the benefit of consumers, the quality and variety of offered products etc. ${ }^{129}$ Whilst in other industries, competition takes place primarily through standard price competition and, possibly, also via incremental innovations, in innovative and dynamic industries the primary and distinguishing feature lies in the fact that incumbents engage in dynamic competition for rather than in the market. ${ }^{130}$

\footnotetext{
128 Type I error denotes overenforcement.

${ }^{129}$ Josef Bejcek, 'Mergers and new technologies' (2005) 36(7) IIC 809, 821

130 Geradin, Damien and Ahlborn, Christian and Denicolò, Vincenzo and Padilla, Jorge, DG Comp's Discussion Paper on Article 82 Implications of the Proposed Framework and Antitrust Rules for Dynamically Competitive Industries (March 2006), 15 et seq. See also on disruptive innovation Graef, Inge; Wahyuningtyas, Sih Yuliana; Valcke, Peggy (2014) How Google and others upset competition analysis disruptive innovation and European competition law, $25^{\text {th }}$ European Regional Conference of the International Telecommunications Society (ITS), Brussels, Belgium, 22-25 June 2014, available at < http//econstor.eu/bitstream/10419/101378/1/795226780.pdf >.
} 
Drawing on Schumpeterian thought and the notion of market evolution and competition relating to a process of so-called 'creative destruction' that threatens the very basis of survival and existence of market participants irrespective of their respective profit margins, ${ }^{131}$ we can argue that drastic innovation makes market leadership highly contestable. ${ }^{132}$ The Commission has admitted that it aims at protecting innovation growth while keeping markets contestable and allowing for profitable returns on investments. ${ }^{133}$

An important implication for antitrust intervention design as well as for the appropriateness of the conventional toolkit for competitive assessment of industries and markets characterised by intense innovation is that we should refrain from adopting a per se approach (in unilateral conduct cases) ${ }^{134}$ or tough sanctions (e.g. large fines/extensive remedies in unilateral conduct cases/concentrations) in dynamic innovative markets, as there are clear reasons to approach innovative and novel practices with caution. ${ }^{135}$ This relates to both unilateral conduct enforcement (as regards liability, remedy and fine) as well

\footnotetext{
131 Joseph A. Schumpeter, Capitalism, Socialism and Democracy, Harper Collins Publishers 1984 ed., 1942, page 84 .

132 Geradin, Damien and Ahlborn, Christian and Denicolò, Vincenzo and Padilla, Jorge, DG Comp's Discussion Paper on Article 82 Implications of the Proposed Framework and Antitrust Rules for Dynamically Competitive Industries (March 2006), 15, available at SSRN <http//ssrn.com/abstract=894466>.

133 Johannes Laitenberger, Competition And Innovation, CRA Annual Brussels Conference (1st edn, 2015) $<$ http://ec.europa.eu/competition/speeches/text/sp2015_04_en.pdf $>$

${ }^{134}$ Crane eloquently emphasizes, 'antitrust law should never seek to destroy dominance by prohibiting dominant firms from innovating to keep up with their customers' changing demands.' Crane D., Search neutrality and referral dominance, Jnl of Competition Law \& Economics (2012) 8 (3) 459-468

135 Galloway J., Driving Innovation a case for targeted competition policy in dynamic markets, http//ssrn.com/abstract=1763676
} 
as the nature of theories of harm and nature, structure as well as extent of remedies in merger enforcement.

In dynamic markets and in the absence of sector regulation the potential risk of overenforcement (Type I errors) should be preferable to under-enforcement (Type II errors), ${ }^{136}$ but competition authorities should also bear in mind that there are greater social costs with Type I errors than Type II errors, ${ }^{137}$ as the market should self-correct Type II errors more readily than Type I errors. ${ }^{138}$ Thus, a rule of reason approach in cases that relate to dynamically innovative industries, can ensure competitors' access to necessary assets without impeding a firm's innovation drive for product development and distribution. ${ }^{139}$

Turning in particular to the design of remedies, as the development of competition enforcement usually lags behind the pace of innovation, the technological development as well as the structural changes in dynamic markets, there is the risk that competition authorities may intervene and seek remedies but by the time the remedies is in place, the market will have changed significantly rendering the remedy ineffective.

\footnotetext{
136 Galloway J., Driving Innovation a case for targeted competition policy in dynamic markets, http//ssrn.com/abstract $=1763676$

137 Easterbrook F., The Limits of Antitrust, (1984) 63 Texas L. Rev. 1, and Manne G. and Wright J., Innovation and the Limits of Antitrust, (2010) 6(1) J. Competition L. \& Econ. 153.

138 Galloway J., Driving Innovation a case for targeted competition policy in dynamic markets, http//ssrn.com/abstract $=1763676$

${ }^{139}$ Gifford D., Kurdle R., Antitrust approaches to dynamically competitive industries in the united states and the European Union, Jnl of Competition Law \& Economics (2011) 7 (3) 695-731, 726.
} 
The Microsoft remedy in relation to the Media Player is one example and a similar argument was being put forward by Commissioner Almunia ${ }^{140}$ when he was deliberating the possibility of commitments in the Google case. The impact of the remedies in the Google case remains to be seen, but initial views of the Commission seem to indicate that the remedies have the desired effect, ${ }^{141}$ albeit competitors still fiercely argue that the impact is not significant and the Commission needs to intervene. ${ }^{142}$ Interestingly in the Google Android case, ${ }^{143}$ as one of the remedies, Google announced a licence fee on mobile manufacturers. ${ }^{144}$ One can envisage the scenario whereby large manufacturers will be in a

${ }^{140}$ The industry we are looking at is also particularly fast moving, because online search itself is constantly evolving. Since we started the investigation, the way search results are presented and the kind of services provided have changed many times...My responsibility when enforcing the antitrust rules in this case is to make sure that Internet users are provided with choice, so they can decide between services based on their merits, and to preserve incentives to innovate across the board, so that users can benefit from new or better services tomorrow...Antitrust is not an adequate instrument to impose on Google a specific algorithm or to prevent Google from improving its services if it wishes to do so. Nor, as a competition authority, can the Commission act in this case as a regulator for all the issues arising in the online world or raised by stakeholders regarding Google. http://europa.eu/rapid/press-release_SPEECH-13-768 en.htm

${ }^{141}$ Indicatively, https://globalcompetitionreview.com/article/1170666/google-shopping-remedies-have-hadeffect-vestager-says, https://www.reuters.com/article/us-eu-alphabet-inc-antitrust/google-shows-progressin-addressing-competition-concerns-says-eus-vestager-idUSKCN1MF28Q

${ }^{142}$ Open letter to EU Commissioner Vestager about Google remedies http://www.preiskel.com/tag/google-shopping/, Google antitrust remedy delivers few changes for rivals https://www.ft.com/content/b3779ef6-b974-11e7-8c12-5661783e5589

143 This paper does not focus on this case as the decision is not published yet.

144 The details/licence levels are still unclear at the time of writing. Reports mention that Google will charge hardware firms up to $\$ 40$ per device to use its apps under a new licensing system to replace one that the European Union this year deemed anti-competitive, Reuters, Google to charge Android partners up to $\$ 40$ per device for apps - source, by Foo Yun Chee and Paresh Dave. See also 
position to pay the fee and at the same time maintain their innovation focus, however, smaller ones may struggle. In addition the price of the product for consumers may rise if manufacturers pass on the cost of the licence fee. Thus, not only innovation in this market may not improve as smaller manufacturers may face difficulties, but the price of the mobile phones based on the Android software to consumers may rise as well, an outcome that the Commission should have taken or may indeed have taken into consideration as a possibility in the assessment of the harm arising from Google's conduct.

The remedies in the concentrations in the pharmaceutical sector that this paper presented, appear to be narrow focusing on the overlaps in commercialised products or R\&D pipelines that the Commission identified in its analysis. This follows its standard analysis in horizontal mergers. The two exceptions appear to be the two concentrations in the agrochemical sector, Dow/Dupont ${ }^{145}$ and Bayer/Monsanto ${ }^{146}$ where, as discussed above, the remedies focus on addressing competition harm in antitrust spaces rather than antitrust markets and the former in both cases was wider than the latter. These two transactions signify the adoption of a new approach to the assessment of innovation in concentrations.

https://www.silicon.co.uk/mobility/mobile-apps/google-licence-fee-european-238019 https://www.digitaltrends.com/mobile/google-charging-android-device-makers-licensing-fee-for-google$\underline{\text { services-europe/ }}$

${ }^{145}$ Case M. 7932 Dow/Dupont dated 27.3.2017

${ }^{146}$ M.8084 Bayer/Monsanto, unreported 
Competition authorities should minimise the outcome of over-deterring welfare-enhancing innovations. ${ }^{147}$ Such innovation drive is what makes markets competitive, as in dynamic markets innovation drives competition. ${ }^{148}$ Competition enforcement should be cautious in mitigating innovation efforts through competition enforcement unless of course consumer harm can be documented. The innovation aspect can be deemed critical and decisive with regard to the outcome of competition enforcement cases related to unilateral conduct as well as concentrations.

\footnotetext{
${ }^{147}$ Manne G., Rinehart W., The Market Realities that Undermined the FTC's Antitrust Case Against Google, Harvard Journal of Law \& Technology Occasional Paper Series, July 2013, 12

148 As Waller and Sag argue the insights of Shumpeter in relation to innovation being the key to growth and that creative destruction is a vital source of innovation are well accepted. Shumpeter has noted that the process of creative destruction relates to a powerful incumbent firm, which is being overwhelmed by new forms of innovation that radically changed the nature of competition. In Weber Waller S., \& Sag M., Promoting Innovation, Iowa Law Review, Vol. 1002223 - 2247, 2226. JA Schumpeter, Capitalism, Socialism and Democracy (5th edn, George Allen \& Unwin 1976).
} 